\title{
Two male-killing Wolbachia strains coexist within a population of the butterfly Acraea encedon
}

\author{
FRANCIS M. JIGGINS*†, GREGORY D. D. HURST \\ SCHULENBURG $\dagger \S \&$ MICHAEL E. N. MAJERUS $\dagger$ \\ $\dagger$ Department of Genetics, Cambridge University, Downing Street, Cambridge, CB2 3EH, U.K. and $\ddagger$ Department of \\ Biology, University College London, 4 Stevenson Way, London, NW1 2HE, U.K.
}

\begin{abstract}
Inherited bacteria that kill male hosts early in their development are known from five insect orders. We ask to what extent the incidence of male-killers might be restricted by the rate at which new hostparasite interactions arise, by testing whether multiple male-killers have invaded a single host species. In Uganda, the butterflies Acraea encedon and A. encedana are both infected by the same strain of male-killing Wolbachia and there was no evidence of variation within the population. In Tanzanian A. encedon however, two phylogenetically distinct strains of male-killing Wolbachia were found within the same population. If this pattern of male-killer polymorphism is found to be general across infected species, it suggests that new male-killing infections arise frequently on an evolutionary time scale. Whether this polymorphism is stable, and what forces may be maintaining it, are unknown.
\end{abstract}

Keywords: Acraea encedana, Acraea encedon, Lepidoptera, male-killing, sex ratio, Wolbachia.

\section{Introduction}

Maternally inherited genes and the rest of the genome are under conflicting selection pressures regarding the sex ratio of their offspring. Natural selection favours maternally inherited genes if they cause the production of daughters only, whereas, all else being equal, the autosomal genes are selected to produce equal numbers of sons and daughters (Fisher, 1930; Hamilton, 1967). Maternally inherited symbionts have evolved several strategies to increase the number or fecundity of daughters, one of the most widespread of which is to kill males early in development. These bacteria spread by kin selection, because male death benefits the female survivors who will pass the bacteria to their offspring (Hurst et al., 1997). Their spread will have direct evolutionary consequences for the host by selecting for suppressors of the transmission and action of the bacteria, and indirect effects associated with the sex ratio bias they produce. In the butterflies $A$. encedon and $A$. encedana the sex ratio distortion can be so extreme as

*Correspondence. E-mail: fmj1001@mole.bio.cam.ac.uk

§Present address: Abteilung für Evolutionsbiologie, Institut für Spezielle Zoologie, Westfälische Wilhelms-Universität Münster, Hüfferstr. 1, 48149 Münster, Germany. to cause sex-role reversal in the host species (Jiggins et al., 2000a; Randerson et al., 2000a).

There appear to be few genetic constraints to the evolution of male-killing. Male-killers are known from five insect orders with varied sex determination mechanisms, suggesting that they are not restricted to particular host genetic systems. Similarly, the male-killing bacteria themselves are surprisingly diverse, the phenotype having independently evolved at least six times across the Eubacteria (Hurst et al., 1999a). Therefore, relative to other forms of bacterial sex ratio distortion, the trait of male-killing is easily evolved by bacteria.

In the absence of genetic constraints, the incidence of male-killers will depend upon which hosts have ecologies that permit their spread and the rate at which malekillers arise in these hosts. Records of male-killers are mostly confined to host species with strong sibling interactions, thus confirming the importance of host ecology in determining the incidence of male-killers. We ask whether the incidence of male-killers is also restricted by the rate at which new host-parasite interactions arise.

We can test whether new interactions occur frequently during evolution by examining species where a malekiller is known, and seeing if more than one element is present, as these are known permissive species. In Adalia bipunctata this approach showed the presence of malekillers from three bacterial genera, suggesting a high rate 
of invasion by novel male-killers (Hurst et al., 1999a; Hurst et al., 1999b). However, this example may prove to be exceptional, as a smaller sample of another ladybird, Harmonia axyridis, contained only one male-killer (Majerus et al., 1999). Further data are clearly necessary.

We aim to test these ideas in a second insect order by investigating in more detail the butterflies $A$. encedon and $A$. encedana, which are known to be host to malekilling Wolbachia bacteria (Jiggins et al., 1998, 2000b; Hurst et al., 1999a). We address three questions. First, how many times has the butterfly $A$. encedon been invaded by male-killers? Second, are multiple malekillers maintained within a population and do the causes of male-killing vary between populations? Finally, do any new male-killing agents identified in $A$. encedon also occur in A. encedana?

\section{Methods}

\section{Identification of male-killing lines}

We used male-killing lines previously identified from Ugandan populations of A. encedon (Jiggins et al., 1998) and $A$. encedana (Jiggins et al., 2000b) and reared additional lines of $A$. encedon from a population in Tanzania, where distorted sex ratios were recorded in 1974 (Owen \& Smith, 1991). Tanzanian butterflies were collected from swampy areas (mostly within a patch of approximately $200 \mathrm{~m} \times 100 \mathrm{~m}$ ) on the University of Dar es Salaam campus in June 1999. Following oviposition on the host plant Commelina sp., the eggs and newly emerged larvae were counted to give hatch rates. In order to increase the data set, additional egg clutches were obtained from the $F_{1}$ generation, their hatch rates recorded, and then they were discarded. The larvae were transported to Cambridge, UK and reared on Commelina benghalensis in a greenhouse. When the adults emerged, some were mated in order to rear a second generation. Male-killer matrilines were identified on the basis of their low egg hatch rates combined with femalebiased sex ratios.

\section{Are all male-killing lines infected by Wolbachia?}

We had previously shown that nine male-killer lines of A. encedon from Uganda were all infected with Wolbachia (Hurst et al., 1999a). We then looked for different male-killers in A. encedon by testing the Tanzanian and further Ugandan male-killer lines for Wolbachia. DNA was extracted from the ovaries of female butterflies using a method modified from Walsh et al. (1991). A small amount of ovary tissue was incubated at $56^{\circ} \mathrm{C}$ with Chelex 100 ion exchange resin (Bio-Rad), dithiothreitol and proteinase- $\mathrm{K}$, then boiled and the supernatant used directly for PCR. We tested for the presence of Wolbachia using the PCR primers wsp $81 \mathrm{~F}$ and wsp691R, which amplify the bacterium's wsp gene (Zhou et al., 1998). The extractions that tested negative for Wolbachia were then amplified using primers for the ITS1 region in insects (Hillis \& Dixon, 1991) to check that the DNA extraction had been successful.

\section{Are all Wolbachia infections the same?}

The $w s p$ gene was amplified as above from Tanzanian and additional Ugandan male-killer matrilines and the PCR product purified using Microcon-50 Microconcentrators (Amicon Ltd). One strand was sequenced in totality direct from the PCR product using one of the PCR primers. Sequencing was performed by cycle sequencing using the ABI PRISM Dye Terminator cycle sequencing ready reaction kit (Perkin Elmer), visualizing the results on an ABI 384 automated sequencer (Perkin Elmer). When a new sequence was identified, the second PCR primer was used to sequence the gene in the opposite direction.

In order to increase our sample size and the geographical range covered, we also sequenced the $w s p$ gene from infected wild females of unknown sex ratio type from Ghana, Zimbabwe (Victoria Falls) and Tanzania (Dar campus). Having identified a novel Wolbachia in the Tanzanian population of $A$. encedon, we then screened a larger Ugandan sample for this bacterium. The restriction enzyme EcoRV cuts the wsp sequence of the new strain (T) but not the previously identified male-killer (strain U). Therefore, we amplified the wsp gene from additional Ugandan male-killer lines and digested them with Eco RV, alongside controls of known $\mathrm{T}$ and $\mathrm{U}$ sequences.

\section{Antibiotic curing of lines infected with novel Wolbachia}

In order to check that newly identified Wolbachia strains found in male-killer lines were causing the male-killing trait, we fed caterpillars from these lines on leaves painted on one side with $1 \% \mathrm{w} / \mathrm{v}$ tetracycline hydrochloride. The resulting butterflies were mated and their offspring's sex ratios recorded. The offspring were then tested with the wsp primer to check whether the antibiotics had cured them of the Wolbachia infection.

\section{The phylogeny of Wolbachia}

The newly isolated $w s p$ sequence from A. encedon $\mathrm{T}$ was added to the previous alignment of Schulenburg et al. (2000), excluding some highly similar sequences from Trichogramma spp. to enhance the speed of tree reconstruction. We excluded regions of the gene that are 
impossible to align because they are highly variable and contain insertions and deletions. Phylogenetic analysis was performed with the program PAUP*, written by David L. Swofford, using the maximum likelihood criterion and the general time reversible substitution model with gamma-distributed substitution rate heterogeneity across sites (Swofford et al., 1996). Tree reconstruction was based on branch-swapping by nearest-neighbour interchanges. The robustness of the inferred topology was assessed by performing 100 nonparametric bootstrap replicates using the same settings as above. In addition, the hypothesis of a single origin of male-killing Wolbachia from A. encedon was tested with the Kishino-Hasegawa test (Kishino \& Hasegawa, 1989). For this purpose, phylogenetic trees were inferred as above, with the topological constraint of exclusive monophyly for these two taxa. The resulting likelihood score was then compared to that of the optimal tree, inferred without such constraints. Schulenburg et al. (2000) give further details of the methods and substitution model used.

\section{Results}

\section{Are all male-killing lines infected by Wolbachia bacteria?}

The sample of $A$. encedon collected in Tanzania contained 54\% females $(n=35)$ and 11 of the 19 females were infected with Wolbachia. Eggs were obtained from 13 of these females; eight infected females produced only daughters (Table 1) and had low hatch rates (Fig. 1),

Table 1 The inheritance of sex ratio from Tanzanian Acraea encedon arranged in maternal lines. The sex ratios of the normal sex ratio broods were homogeneous (including the antibiotic-cured brood: $\chi^{2}=6.1$; d.f. $=10$; NS) and did not differ from a 1:1 sex ratio (summed data: 462 males: 477 females)

\begin{tabular}{lccccc}
\hline & \multicolumn{2}{c}{ Parental } & & \multicolumn{2}{c}{$F_{1}$} \\
\cline { 2 - 3 } \cline { 5 - 6 } Sex ratio & Male & Female & & Male & Female \\
\hline All-female & 0 & 45 & & 0 & 30 \\
All-female & 0 & 10 & & 0 & 69 \\
All-female & 0 & 18 & & 0 & 51 \\
All-female & 0 & 11 & & 0 & 33 \\
All-female & 0 & 28 & & 0 & 31 \\
All-female & 0 & 27 & & \\
All-female & 0 & 18 & & 0 & 64 \\
All-female & 0 & 17 & & \\
Normal & 22 & 16 & & 23 & 24 \\
Normal & 59 & 54 & & 36 & 33 \\
Normal & 22 & 27 & & \\
Normal & 30 & 30 & & & \\
Normal & 38 & 33 & & 22 & 18 \\
\hline
\end{tabular}

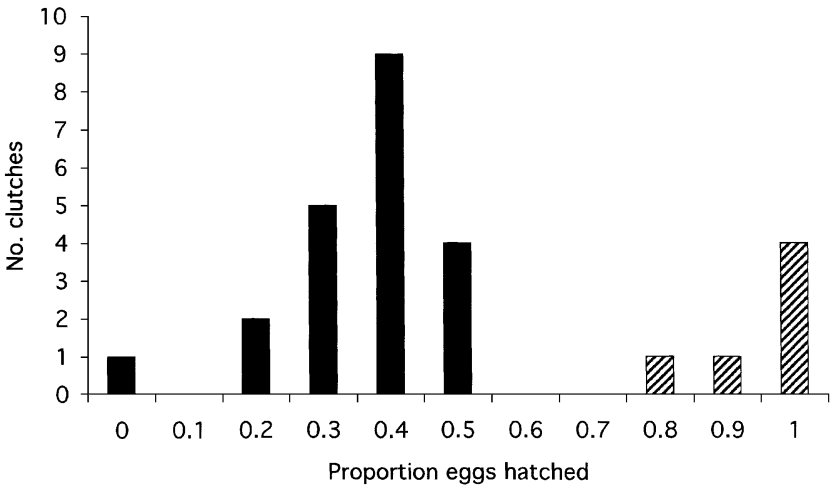

Fig. 1 Hatch rates of all-female (filled) and normal sex ratio (hatched) Tanzanian A. encedon broods. All-female broods have lower hatch rates than normal sex ratio broods (Mann-Whitney $U$-test: $n 1=21, n 2=6 ; U=20 ; P<0.05$ ).

indicating the presence of a male-killer. Five uninfected females produced normal sex ratios. Twenty-one Ugandan male-killer lines were all infected with Wolbachia (12 from this study, nine from Hurst et al., 1999a).

\section{Are all Wolbachia infections the same?}

Two different Wolbachia wsp sequences were isolated from the 11 infected Tanzanian $A$. encedon females. Four females were infected with strain $\mathrm{U}$, which was identical to the Ugandan male-killer (Hurst et al., 1999a). The remaining seven females were infected with strain $T$, which differs from strain $U$ by one 3-bp insertion and approximately 100 nucleotide substitutions $(6 \%$; precise alignment of some homologous sites was difficult due to the position of the insertion being uncertain). In contrast, there was no variation in the Wolbachia wsp gene isolated from A. encedon collected in Uganda $(n=7)$, Ghana $(n=1)$ or Zimbabwe $(n=2)$, with all these infections being strain U. Similarly, the Ugandan population of $A$. encedana $(n=22)$ was only infected with strain U. The wsp PCR product from a further 13 Ugandan specimens of A. encedon did not cut with EcoRV, which cuts strain T but not strain U.

Phylogenetic analysis of $w s p$ gene sequences strongly suggested that these two strains fall into different clades within the B-group Wolbachia (bootstrap support $>50$; Fig. 2). This is confirmed by the results of the KishinoHasegawa test, which reject the hypothesis of exclusive monophyly of these strains $(\Delta l=159.016$; $\mathrm{SD}=16.968$; $T=9.372 ; P<0.0001)$.

\section{Is the new Wolbachia strain killing males?}

Two broods were reared from lines infected with the newly identified Wolbachia strain that had been fed on antibiotics. The resulting sex ratios were 85 males: 85 


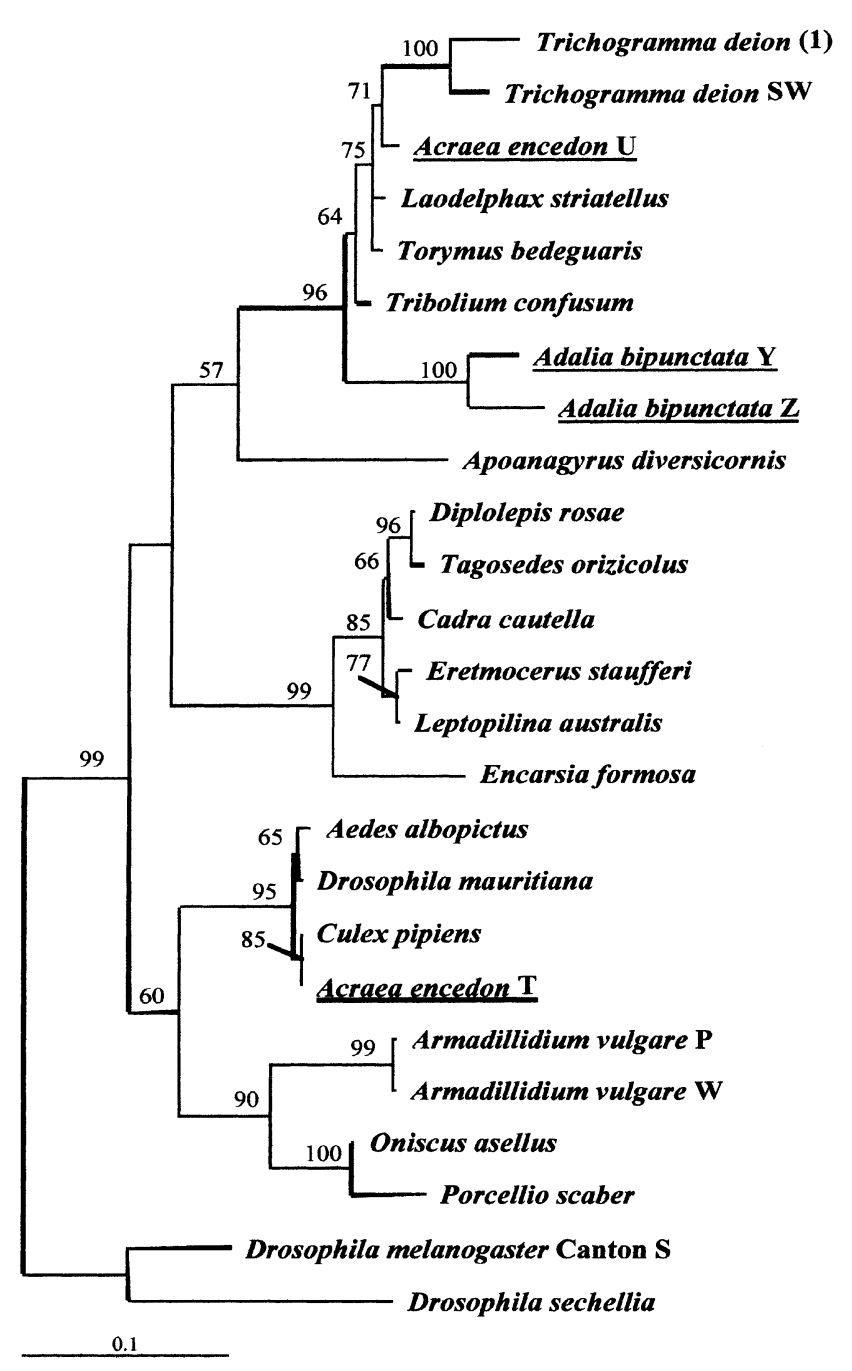

Fig. 2 Maximum likelihood phylogeny of the B-group Wolbachia wsp gene. The labels refer to the host species and male-killing strains are underlined. The tree is rooted with Drosophila melanogaster, strain Canton S, and D. sechellia. The figure shows one of three topologies with identical likelihoods $(l=-3031.922)$ that differ only in the position of the L. striatellus and T. bedeguaris relative to A. encedon $\mathrm{U}$, and the two Trichogramma species. The results of 100 bootstrap replicates are shown above the branches.

females and 1 male: 0 females. As a control these broods were reared alongside the $F_{1}$ generation shown in Table 1, which were treated identically, except for the presence of antibiotics. Antibiotic treatment did not alter the sex ratio of two normal sex ratio lines (33 males: 39 females and 92 males: 118 females).

\section{Discussion}

From this study we can conclude that two different male-killing Wolbachia strains occur sympatrically in the Tanzanian population of $A$. encedon. In contrast, we found no evidence of male-killer polymorphisms in Ugandan populations of either $A$. encedon or $A$. encedana. Similarly, there was no evidence of malekillers from other bacterial groups in either butterfly. Within the $\mathrm{T}$ and $\mathrm{U}$ strains there was no sequence variation, suggesting that relatively recent invasions or selective sweeps have occurred.

The other insect in which a diversity of male-killers within a population has been found is the two-spot ladybird, Adalia bipunctata. In this species, from one to four different male-killers occur within single populations (Hurst et al., 1999b; Majerus et al., 2000). These male-killers belong to three bacterial genera, Spiroplasma, Rickettsia and two strains of Wolbachia. In contrast to the two Wolbachia in A. encedon, the two Wolbachia strains in A. bipunctata form a monophyletic group. The only other species where the diversity of male-killers has been investigated is another ladybird, Harmonia axyridis, where 19 male-killer lines were all infected with Spiroplasma bacteria. However, gene sequence data were not obtained from all these lines to test whether these bacteria were monophyletic within the genus Spiroplasma (Majerus et al., 1999).

Wolbachia that cause cytoplasmic incompatibility and induce parthenogenesis are known, on an evolutionary time scale, to frequently move between host species (Werren et al., 1995; Schilthuizen \& Stouthamer, 1997). Our observations suggest that this may be true for all Wolbachia phenotypes, and we predict that further cases of multiple male-killer strains within species will be discovered.

The two male-killers were found within the same population. Multiple strains of Wolbachia that cause cytoplasmic incompatibility (CI) commonly coexist within a host population, with two or more bacterial strains infecting single individuals (Rousset \& Solignac, 1995). This is expected from classical models of cytoplasmic incompatibility, which predict that a second bacterial strain can invade an infected host population provided that it is of a different crossing type and initially arises in a female infected with the original strain (Hoffmann \& Turelli, 1997). In contrast, simple models of sex-ratio-distorting Wolbachia do not predict the presence of multiple bacterial strains within a single population. As predicted, the parthenogenesis-inducing Wolbachia from a single population of Trichogramma kaykai were all found to fall into a monophyletic group (Schilthuizen et al., 1998). Currently no data exist on the diversity of feminizing Wolbachia within populations.

The cause of male-killer polymorphisms is a matter for speculation. It is possible that we have observed a transient polymorphism, as one male-killer replaces the other. Alternatively, the two male-killers may be 
favoured in different populations by environmental or host genetic factors, and we may have observed mixing between these populations. However, if the polymorphism is stably maintained within the population, then this situation cannot be explained by simple models of male-killer dynamics (Randerson et al., 2000b). The incorporation into these models of costly autosomal resistance genes, each specific to a particular male-killer, provides a means by which polymorphisms can be maintained (Randerson et al., 2000b). This closely resembles the better characterized situation in plants, where both male-sterile cytotypes and autosomal loci that restore male fertility in the presence of specific cytotypes may be highly polymorphic (Van Damme \& Van Delden, 1982; Laughnan \& Gabay-Laughlan, 1983).

The known male-killing Wolbachia fall into three clades on our phylogeny of the bacterium's surface protein gene $(w s p)$, and we were able to reject the hypothesis that the two $A$. encedon sequences are monophyletic. Assuming that the male-killing phenotype is encoded by bacterial and not host genes, this suggests that either male-killing has evolved multiply or that Wolbachia lineages recombine, meaning that our phylogeny does not reflect the evolutionary history of the male-killing phenotype (see discussion in Schulenburg et al., 2000). This can only be resolved by identifying the gene(s) that cause the male-killing trait itself.

\section{Acknowledgements}

Ian Gordon (Kipepeo Project, National Museums of Kenya) and David Smith (Eton College) kindly collected specimens in Ghana, Zimbabwe and a preliminary sample from Tanzania. This work was in collaboration with the Department of Zoology, Makerere University, Uganda, and was funded by a BBSRC studentship to FMJ and a BBSRC D. Philips' Fellowship to GDDH.

\section{References}

FISHER, R. A. 1930. The Genetical Theory of Natural Selection. Dover, New York.

Hamilton, w. D. 1967. Extraordinary sex ratios. Science, 156, 477-488.

HILlis, D. M. AND DIXON, M. T. 1991. Ribosomal DNA: molecular evolution and phylogenetic inference. $Q$. Rev. Biol., 66, 411-453.

hofFMANN, A. A. AND TURelli, M. 1997. Cytoplasmic incompatibility in insects. In: O'Neill, S. L., Hoffmann, A. A. and Werren, J. H. (eds) Influential Passengers: Microbes and Invertebrate Reproduction, pp. 125-154. Oxford University Press, Oxford.

HURST, G. D. D., HURST, L. D. AND MAJERUS, M. E. N. 1997. Cytoplasmic sex ratio distorters. In: O’Neill, S. L., Hoffmann,
A. A. and Werren, J. H. (eds) Influential Passengers: Microbes and Invertebrate Reproduction, pp. 125-154. Oxford University Press, Oxford.

HURST, G. D. D., JIGGINS, F. M., SCHUlenberG, J. H. G., BERTRAND, D., WEST, S. A., GORIACHEVA, I. I. ET AL. 1999a. Male-killing Wolbachia in two species of insect. Proc. $R$. Soc. Lond. B, 266, 735-740.

HURST, G. D. D., SCHUlenburG, J. H. G., MAJERUS, T. M. O., BERTRAND, D., ZAKHAROV, I. A., BAUNGAARD, J. ET $A L .1999$ b. Invasion of one insect species, Adalia bipunctata, by two different male-killing bacteria. Insect Mol. Biol., 8, 133-139.

JiGgins, F. M., HURST, G. D. D. AND MAJERUS, M. E. N. 1998. Sex ratio distortion in Acraea encedon (Lepidoptera: Nymphalidae) is caused by a male-killing bacterium. Heredity, 81, 87-91.

JigGins, F. M., HURST, G. D. D. AND MAJerus, M. E. N. 2000a. Sex ratio distorting Wolbachia cause sex role reversal in their butterfly hosts. Proc. R. Soc. Lond. B, 267, 69-73.

JiGGiNS, F. M., HURST, G. D. D., DOLMAN, C. E. AND MAJERUS, M. E. N. 2000b. High prevalence male-killing Wolbachia in the butterfly Acraea encedana. J. Evol. Biol., 13, 495-501.

KISHINO, H. AND HASEGAWA, M. 1989. Evaluation of the maximum likelihood estimate of evolutionary tree topologies from DNA sequence data, and the branching order in the Hominoidea. J. Mol. Evol., 29, 170-179.

LAUGHNAN, J. R. AND S. GABAY-LAUGHLAN. 1983. Cytoplasmic male sterility in maize. Ann. Rev. Genet., 17, 27-48.

MAJERUS, T. M. O., MAJERUS, M. E. N., SCHULENBURG, J. H. G. V. D. AND HURST, G. D. D. 1999. Molecular identification of a malekilling agent in the ladybird Harmonia axyridis (Pallas) (Coleoptera: Coccinellidae). Insect Mol. Biol., 8, 551-555.

MAJERUS, M. E. N., SCHULENBURG, J. H. G. V. D. AND ZAKHAROV, I. A. 2000. Multiple causes of male-killing in a single sample of the 2-spot ladybird, Adalia bipunctata (Coleoptera: Coccinellidae) from Moscow. Heredity, 84, 605-609.

OWEN, D. F. AND SMITH, D. A. S. 1991. All-female broods and mimetic polymorphism in Acraea encedon (L.) (Lepidoptera: Acraeidae) in Tanzania. Afr. J. Ecol., 29, 241-247.

RANDERSON, J. P., JIGGINS, F. M. AND HURST, L. D. 2000a. Malekilling can select for male mate choice: a novel solution to the paradox of the lek. Proc. R. Soc. Lond. B, 267, 867-874.

RANDERSON, J. P., SMITH, N. G. C. AND HURST, L. D. 2000b. The evolutionary dynamics of male-killers and their hosts. Heredity, 84, 152-160.

ROUSSET, F. AND SOlignaC, M. 1995. Evolution of single and double symbioses during speciation in the Drosophila simulans complex. Proc. Natl. Acad. Sci. U.S.A., 92, 63896393.

SCHILTHUIZEN, M. AND STOUTHAMER, R. 1997. Horizontal transmission of parthenogenesis-inducing microbes in Trichogramma wasps. Proc. R. Soc. Lond. B., 264, 361-366.

SCHILTHUIZEN, M., HONDA, J. AND STOUTHAMER, R. 1998. Parthenogenesis inducing Wolbachia in Trichogramma kaykai (Hymenoptera: Trichogrammatidae) originates from a single infection. Ann. Ent. Soc. Am., 91, 410-414.

SCHUlENBURG, J. H. G. V. D., HURST, G. D. D., HUIGENS, T. M. E., VAN MEER, M. M. M., JIGGINS, F. M. AND MAJERUS, M. E. N. 2000. Molecular evolution and phylogenetic utility of Wolbachia 
$f t s Z$ and wsp gene sequences with special reference to the origin of male-killing. Mol. Biol. Evol., 17, 584-600.

SWOFFORD, J. L., OLSEN, G. J., WADDELL, P. J. AND HILLIS, D. M. 1996. Phylogenetic inference. In: Hillis, D. M., Moritz, C. and Mable, B. K. (eds) Molecular Systematics, pp. 407-514. Sinauer Associates, MA, USA.

VAN DAMME, J. M. M. AND VAN DELDEN, w. 1982. Gynodioecy in Plantago lanceolata L. I. Polymorphism for plasmon type. Heredity, 49, 303-318.
WALSH, P. S., METZGER, D. A. AND HIGUCHI, R. 1991. Chelex 100 as a medium for simple extraction of DNA for PCR based typing of forensic material. Biotechniques, 10, 506-513.

WERREN, J. H., ZHANG, W. AND GUO, L. R. 1995. Evolution and phylogeny of Wolbachia: reproductive parasites of the arthropods. Proc. R. Soc. B, 261, 55-71.

ZHOU, w. F., ROUSSET, F. AND O'NEILL, s. 1998. Phylogeny and PCR based classification of Wolbachia strains using wsp gene sequences. Proc. R. Soc. Lond. B, 265, 509-515. 